\title{
Analisis Kebutuhan dan Motivasi Wali Santri terhadap Keputusan memilih Pesantren AL WAFI IBS Pengasinan
}

\author{
Sairin', Chotamul Fajri², ${ }^{2}$,uworo ${ }^{3}$ \\ 1,2,3 Fakultas Ekonomi dan Bisnis, Universitas Pamulang, Tangerang Selatan, Indonesia \\ E-mail: dosen01517@unpam.ac.id
}

\begin{tabular}{l}
\hline Article Info \\
\hline Article History \\
Received: 2021-03-02 \\
Revised: 2021-06-10
\end{tabular}

Published: 2021-06-27

Keywords:

Needs Analysis;

Motivation

Decision;

Boarding school.

\begin{abstract}
The purpose of this study was to determine the effect of the need (X1) of guardianship on the decision to choose a modern Islamic boarding school Al Wafi Islamic Boarding School (Y), to determine the effect of motivation (X2) of guardianship on the decision to choose a modern Islamic boarding school Al Wafi Islamic Boarding School ( Y), and to determine the effect of the needs (X1) and motivation (X2) of guardians simultaneously on the decision to choose the modern Islamic boarding school Al Wafi Islamic Boarding School partially, The method used is descriptive quantitative method. The sampling technique used is a saturated sample / census, if all members of the population are used as samples. In this study, the sample used by prospective guardians who registered used a sample of 75 respondents. Data analysis used regression analysis, correlation coefficient analysis, coefficient of determination analysis and hypothesis testing, The results of this study that the variable needs (X1) Walisantri had no influence on the decision to choose a modern Islamic boarding school Al Wafi Islamic Boarding School (Y), for the motivation variable (X2) Walisantri had an influence on the decision to choose a modern Islamic boarding school Al Wafi Islamic Boarding School (Y) and for the variable needs (X1) and motivation (X2) Walisantri there is an influence on the decision to choose the modern Islamic boarding school Al Wafi Islamic Boarding School. Hypothesis testing was obtained based on the calculated $\mathrm{F}$ value.
\end{abstract}

\begin{tabular}{l}
\hline Artikel Info \\
\hline Sejarah Artikel \\
Diterima: 2021-06-02 \\
Direvisi: 2021-06-10 \\
Dipublikasi: 2021-06-27
\end{tabular}

Kata kunci: Analisis Kebutuhan; Motivasi; Keputusan; Pesantren.

\begin{abstract}
Abstrak
Tujuan dalam penelitian ini adalah untuk mengetahui pengaruh antara kebutuhan (X1) walisantri terhadap keputusan memilih pondok pesantren modern Al Wafi Islamic Boarding School (Y), untuk mengetahui pengaruh antara motivasi (X2) walisantri terhadap keputusan memilih pondok pesantren modern Al Wafi Islamic Boarding School (Y), dan untuk mengetahui pengaruh antara kebutuhan (X1) dan motivasi (X2) walisantri secara simultan terhadap keputusan memilih pondok pesantren modern $\mathrm{Al}$ Wafi Islamic Boarding School secara parsial, Metode yang digunakan adalah metode deskriptif kuantitatif. Teknik sampling yang digunakan adalah sampel jenuh/sensus, apabila semua anggota populasi dijadikan sebagai sampel. Dalam penelitian ini sampel yang digunakan calon walisantri yang mendaftar menggunakan sampel sebanyak 75 responden. Analisis data menggunakan analisis regresi, analisis koefisien korelasi, analisis koefisien determinasi dan uji hipotesis, Hasil penelitian ini variabel kebutuhan (X1) Walisantri tidak terdapat pengaruh terhadap keputusan memilih pondok pesantren modern Al Wafi Islamic Boarding School (Y), untuk variabel motivasi (X2) Walisantri terdapat pengaruh terhadap keputusan memilih pondok pesantren modern Al Wafi Islamic Boarding School (Y) serta untuk variabel kebutuhan (X1) dan motivasi (X2) Walisantri terdapat pengaruh terhadap keputusan memilih pondok pesantren modern Al Wafi Islamic Boarding School. Uji hipotesis diperoleh berdasarkan nilai $\mathrm{F}$ hitung.
\end{abstract}

\section{PENDAHULUAN}

Dewasa ini berkembang system pendidikan yang mengembangkan kurikulum umum dan pesantren dengan konsep Islamic Boarding School (IBS) dengan muatan diniah yang lebih banyak dengan tujuan menanamkan nilai nilai akhlaqul karimah pada peserta didik sehingga bisa membentengi berkembangnya kebebasan teknologi informasi melalui social media dan internet, Kondisi saat ini pendidikan pesantren yang dikemas dengan istilah Islamic boarding school merupakan tempat yang paling tepat sebagai pilihan orang tua untuk memberikan pendidikan putra putinya, karena pola pendidikannya hampir 24 jam, Dengan dukungan 
sumberdaya yang menguasai pengetahuan umum, pesantren dan pengasuhan.

Model pendidikan pesantren bertujuan memgembangkan kemampuan manusia dari aspek agama dan model pendidikan sekolah menekankan prestasi akademik dan life skill (kecakapan hidup), Sekolah berbasis pesantren merupakan model pendidikan Islam yang mengintegrasikan keunggulan sistem sekolah dan sistem pesantren, Model pendidikan Islam ini dapat menciptakan manusia yang agamawan sekaligus ilmuwan, sehingga dapat berperan penuh dalam sistem sosial kemasyarakatan, Keputusan orang tua memilih menempatkan anaknya di pesantren agar anaknya belajar ilmu agama dan melatih kemandirian. Dengan banyaknya pilihan pondok pesantren, orang tua harus mempertimbangkan beberapa alasan sesuai kebutuhan yang diinginkan.

Menurut Mulyadi (2012) kebutuhan dapat didefinisikan sebagai sesuatu yang diperlukan, secara alamiah secara etika dan moral harus dipenuhi, Jika dikaitkan dengan pemilihan pondok pesantren bagi siswa, dari data Pondok Pesantren Modern AL WAFI Islamic Boarding School memiliki beberapa karakteristik yang berbeda dari teoritis, seperti adanya kebutuhan mengenai pendidikan di pondok pesantren tidak hanya menitik beratkan pada manfaat yang di dapat tetapi juga ada beberapa yang dipertimbangkan orang tua dalam memilih pondok pesantren bagi anaknya, salah satunya mengenai biaya, pelayanan, sarana prasarana olah raga dan alasan lain adalah pertimbangan mengenai kualitas pondok pesantren. Karena semakin baik kualitas dari pondok pesantren maka semakin baik pula pendidikan yang diajarkannya.

Pesantren AL WAFI mengembangkan jenjang pendidikan tingkat SD, SMP, dan SMA dengan menggunakan kurikulum13 dibawah Kemendikbud dan kurikulum timur tengah yang mengacu kurikulum IUM. Program SD dari kelas satu sampai kelas 4 fullday school, kelas 5, 6 SD, SMP dan SMA berasrama atau pesantren. Pesantren Al Wafi berdiri semenjak tahun 2016 di bawah yayasan Al Sudais Indonesia berinisiatif yang beralamat di Jl Raya Arco No. 1 RT 02 RW 01 Raga Mukti-Kelurahan Citayam Kecamatan Tajurhalang, Kabupaten Bogor.

Tabel 1. Jumlah siswa SMA AL WAFI IBS

\begin{tabular}{lcccc}
\hline \multirow{2}{*}{ Kelas } & \multicolumn{2}{c}{$\mathbf{2 0 1 8 / 2 0 1 9}$} & \multicolumn{2}{c}{$\mathbf{2 0 1 9 / 2 0 2 0}$} \\
\cline { 2 - 5 } & $\mathrm{L}$ & $\mathrm{P}$ & $\mathrm{L}$ & $\mathrm{P}$ \\
\hline $\mathrm{X}$ & 52 & 22 & 97 & 34 \\
\hline
\end{tabular}

\begin{tabular}{lcccc}
\hline XI & 14 & 7 & 53 & 25 \\
\hline XII & 16 & - & 13 & 8 \\
\hline Jumlah & $\mathbf{8 2}$ & $\mathbf{2 9}$ & $\mathbf{1 6 3}$ & $\mathbf{6 7}$ \\
\hline Total & \multicolumn{3}{c}{$\mathbf{1 1 1}$} & \multicolumn{2}{c}{$\mathbf{2 3 8}$} \\
\hline \multicolumn{3}{c}{ Sumber: SMA AL WAFI IBS }
\end{tabular}

Tabel diatas menjelaskan jumlah santri yang telah mengalami peningkatan walaupun baru berjalan sekitar lima tahunan, Atas dasar kontradiksi mengenai kebutuhan dan motivasi wali santri dalam keputusan memilih pondok pesantren, maka menarik dianalisis mengenai Analisis Kebutuhan dan Motivasi Walisantri dalam Keputusan Memilih Pondok Pesantren AL Wafi Islamic Boarding School Kota Depok, dengan tujuan dalam penelitian ini diantaranya: 1) Untuk mengetahui apakah terdapat pengaruh antara kebutuhan (X1) wali santri secara parsial dalam memilih pondok pesantren modern AL WAFI Islamic Boarding School, 2) Untuk mengetahui apakah terdapat pengaruh antara motivasi (X2) walisantri dalam memilih pondok pesantren modern Al WAFI Islamic Boarding School, 3) Untuk mengetahui apakah terdapat pengaruh antara kebutuhan (X1) dan motivasi (X2) walisantri dalam memilih pondok pesantren modern Al WAFI Islamic Boarding School secara secara simultan, sedangkan manfaat yang menjadi sasaran dalam penelitian ini salah satunya dapat dijadikan Sebagai alternatif sumbangan pemikiran yang dapat digunakan oleh pihak pondok pesantren yang terkait dalam rangka meningkatkan daya saing, terutama tentang kebutuhan motivasi wali santri dalam memilih pondok pesantren

\section{METODE PENELITIAN}

Penelitian ini menggunakan pendekatan kuantitatif, dengan teknik pengumpulan data yang digunakan adalah kuesioner (angket) dan dokumentasi. Kuesioner digunakan untuk mengetahui jawaban dari responden mengenai variabel kebutuhan (X1) dan motivasi (X2) dalam keputusan memilih pondok pesantren modern (Y). Penelitian ini juga memanfaatkan dokumentasi dari pondok pesantren terkait pondok pesantren modern Pesantren Al Wafi IBS, dengan penggunaan skala pengukuran Skala pengukuran yaitu skala likert. Menurut Aminullah (2002), Skala likert digunakan secara luas yang mengharuskan responden untuk menunjukkan derajat setuju atau tidak setuju kepada setiap statemen yang berkaitan dengan objek yang dinilai. Bentuk skala likert memiliki lima ketegori. Apabila dirangking, maka susunannya akan dimulai dari sangat tidak setuju 
(Strongly disagree) sampai kepada sangat setuju (Strong agree), Lima ketegori penilaian dimana masing-masing pernyataan diberi skor $1-5$ diantaranya: STS : Sangat Tidak Setuju (skor : 1 ), TS: Tidak Setuju (skor : 2), KS: Kurang Setuju (skor : 3), S: Setuju (skor : 4), SS: Sangat Setuju (skor : 5), adapun Pupulasi yang digunakan dalam penelitian ini yaitu: seluruh calon walisantri siswa SMA pondok pesantren Al Wafi IBS berjumlah 75 walisantri, sedangkan Pengambilan sampel dilakukan dengan menggunakan sampling jenuh yaitu teknik penentuan sampel jenuh/sensus,apabila semua anggota populasi dijadikan sebagai sampel. Dalam penelitian ini sampel yang digunakan seluruh calon walisantri siswa SMA pondok pesantren Al Wafi IBS (Sugiyono, 2011: 67).

\section{HASIL DAN PEMBAHASAN}

\section{A. Uji Validitas Kebutuhan (X1), Motivasi (X2)} dan Keputusan memilih (Y)

Dalam melakukan uji Validitas Kebutuhan ditentukan berdasarkan hal berikut:

Jika nilai $r$ hitung $>r$ tabel, maka instrument valid, sebaliknya Jika nilai $\mathrm{r}$ hitung $>\mathrm{r}$ tabel, maka instrument valid.

Tabel 2. Uji Validitas Kebutuhan (X1),

Motivasi (X2) dan Keputusan memilih (Y)

\begin{tabular}{|c|c|c|c|c|}
\hline \multicolumn{5}{|c|}{ Correlations } \\
\hline & & $\mathrm{X} 1$ & $\mathrm{X} 2$ & $\mathrm{Y}$ \\
\hline \multirow[t]{3}{*}{$\mathrm{X} 1$} & Pearson Correlation & 1 & $.404^{* *}$ & $.377^{* *}$ \\
\hline & Sig. (2-tailed) & & .000 & .001 \\
\hline & $\mathrm{N}$ & 75 & 75 & 75 \\
\hline \multirow[t]{3}{*}{$\mathrm{X} 2$} & Pearson Correlation & $.404^{* *}$ & 1 & $.905^{* *}$ \\
\hline & Sig. (2-tailed) & .000 & & .000 \\
\hline & $\mathrm{N}$ & 75 & 75 & 75 \\
\hline \multirow[t]{3}{*}{$\mathrm{Y}$} & Pearson Correlation & $.377^{* *}$ & $.905^{* *}$ & 1 \\
\hline & Sig. (2-tailed) & .001 & .000 & \\
\hline & $\mathrm{N}$ & 75 & 75 & 75 \\
\hline
\end{tabular}

Berdasarkan table diatas maka dapat ditarik beberapa kesimpulan antara lain:

$r$ tabel $=0,227$ dari tabel PRODUCT MOMENT, dimana $r$ hitung $1.000>0.227$, maka kebutuhan Valid.

$r$ tabel $=0,227$ dari tabel PRODUCT MOMENT, dimana $r$ hitung $0.404>0.227$, maka motivasi Valid.

$r$ tabel $=0,227$ dari tabel PRODUCT MOMENT, dimana $r$ hitung $0.377>0.227$, maka keputusan memilih Valid.

B. Uji Reliabilitas Kebutuhan (X1), Motivasi (X2) dan Keputusan memilih (Y)

Dalam melakukan Uji Reliabilitas Kebutuhan ditentukan berdasarkan hal berikut:

Jika nilai Cronbach Alpha> 0,6, maka instrument dikatakan Reliabel

Jika nilai Cronbach Alpha 0.744 > 0,6, maka instrument Reliabel
Tabel 3. Uji Reliabilitas Kebutuhan (X1),

Motivasi (X2) dan Keputusan memilih (Y)

\begin{tabular}{llrr}
\hline \multicolumn{5}{c}{ Case Processing Summary } \\
\hline \multirow{3}{*}{ Cases } & $\mathrm{N}$ & $\%$ \\
& Valid & 75 & 100.0 \\
\cline { 2 - 4 } & Excluded $^{\mathrm{a}}$ & 0 & .0 \\
\cline { 2 - 4 } & Total & 75 & 100.0 \\
\hline
\end{tabular}

Listwise deletion based on all variables in the procedure.

\begin{tabular}{r|r}
\hline \multicolumn{2}{c}{ Reliability Statistics } \\
\hline Cronbach's Alpha & N of Items \\
\hline .744 & \\
\hline
\end{tabular}

C. Hubungan Kuat antara Kebutuhan (X1), Motivasi (X2) dan Keputusan memilih (Y)

Dalam menentukan Hubungan Kuat antara Kebutuhan (X1), Motivasi (X2) dan Keputusan memilih (Y) dilakukan berdasarkan hal berikut:

Variabel X1 mempunyai hubungan yang lemah terhadap Y, karena 0.377

Variabel X2 mempunyai hubungan yang kuat terhadap Y, karena 0.905

Tabel 4. Hubungan kuat antara Variabel $\mathrm{X} 1, \mathrm{X} 2$ terhadap Variabel Y

\begin{tabular}{|c|c|c|c|c|}
\hline \multicolumn{5}{|c|}{ Correlations } \\
\hline & & $\mathrm{X} 1$ & $\mathrm{X} 2$ & Y \\
\hline \multirow[t]{3}{*}{$\mathrm{X} 1$} & Pearson Correlation & 1 & $.404^{* *}$ & $.377^{* *}$ \\
\hline & Sig. (2-tailed) & & .000 & .001 \\
\hline & $\mathrm{N}$ & 75 & 75 & 75 \\
\hline \multirow[t]{3}{*}{$\mathrm{X} 2$} & Pearson Correlation & $404^{* *}$ & 1 & $.905^{* *}$ \\
\hline & Sig. (2-tailed) & .000 & & .000 \\
\hline & $\mathrm{N}$ & 75 & 75 & 75 \\
\hline \multirow[t]{3}{*}{$\mathrm{Y}$} & Pearson Correlation & $.377^{* *}$ & $.905^{* *}$ & 1 \\
\hline & Sig. (2-tailed) & .001 & .000 & \\
\hline & $\mathrm{N}$ & 75 & 75 & 75 \\
\hline
\end{tabular}

D. Hasil Pengujian Regresi linier berganda antara Kebutuhan (X1) dan Motivasi (X2) terhadap Keputusan memilih (Y)

Berikut ini disajikan data Hasil Pengujian Regresi linier berganda antara Kebutuhan (X1) dan Motivasi (X2) terhadap Keputusan memilih (Y)

Tabel 5. Regresi Kebutuhan (X1) dan Motivasi (X2) terhadap Keputusan memilih (Y)

\begin{tabular}{|c|c|c|c|c|c|c|}
\hline \multicolumn{7}{|c|}{ Coefficients $^{a}$} \\
\hline & \multirow[t]{2}{*}{ Model } & \multicolumn{2}{|c|}{$\begin{array}{l}\text { Unstandardized } \\
\text { Coefficients }\end{array}$} & \multirow{2}{*}{$\begin{array}{c}\begin{array}{c}\text { Standar } \\
\text { dized } \\
\text { Coefficie } \\
\text { nts }\end{array} \\
\text { Beta }\end{array}$} & \multirow[t]{2}{*}{$\mathrm{t}$} & \multirow[t]{2}{*}{ Sig. } \\
\hline & & B & $\begin{array}{c}\text { Std. } \\
\text { Error }\end{array}$ & & & \\
\hline \multirow[t]{3}{*}{1} & (Constant) & 2.142 & 2.611 & & .820 & .415 \\
\hline & $\mathrm{X} 1$ & .010 & .038 & .014 & .259 & .796 \\
\hline & $\mathrm{X} 2$ & .942 & .057 & .899 & $\begin{array}{r}16.42 \\
0\end{array}$ & .000 \\
\hline
\end{tabular}

Dependent Variable: $\mathrm{Y}$ 
Tabel diatas menjelaskan perolehan persamaan regresi dari $\mathrm{Y}=2,142+$ $0.010 \mathrm{X} 1+0.942 \mathrm{X} 2$, dimana:

a. Nilai konstanta 2,142 diartikan bahwa jika variabel Kebutuhan (X1) dan Motivasi (X2) tidak ada maka telah terdapat Keputusan memilih (Y) sebesar 2,142 points.

b. Setiap perubahan 1 unit pada variabel Kebutuhan (X1) akan mengakibatkan terjadinya perubahan pada Keputusan memilih (Y) sebesar 2,142 points.

c. Setiap perubahan 1 unit pada variabel Motivasi (X2) akan mengakibatkan terjadinya perubahan pada Keputusan memilih (Y) sebesar 2,142 points.

\section{E. Pengaruh Kebutuhan (X1) terhadap Keputusan memilih (Y) dengan Uji T}

Berikut ini disajikan data terkait dengan Pengaruh Kebutuhan (X1) terhadap Keputusan memilih (Y) dengan Uji T

Tabel 6. Pengaruh Kebutuhan (X1), Motivasi

(X2) terhadap Keputusan memilih (Y) dengan Uji T

\begin{tabular}{|c|c|c|c|c|c|c|}
\hline \multicolumn{7}{|c|}{ Coefficients $^{a}$} \\
\hline & \multirow[t]{2}{*}{ Model } & \multicolumn{2}{|c|}{$\begin{array}{l}\text { Unstandardized } \\
\text { Coefficients }\end{array}$} & \multirow{2}{*}{$\begin{array}{c}\begin{array}{c}\text { Standar } \\
\text { dized } \\
\text { Coefficie } \\
\text { nts }\end{array} \\
\text { Beta }\end{array}$} & \multirow[t]{2}{*}{$\mathrm{t}$} & \multirow[t]{2}{*}{ Sig. } \\
\hline & & B & $\begin{array}{l}\text { Std. } \\
\text { Error }\end{array}$ & & & \\
\hline 1 & (Constant) & 2.142 & 2.611 & & .820 & .415 \\
\hline & $\mathrm{X} 1$ & .010 & .038 & .014 & .259 & .796 \\
\hline & $\mathrm{X} 2$ & .942 & .057 & .899 & 16.420 & .000 \\
\hline & ependent $V_{c}$ & le: $Y$ & & & & \\
\hline
\end{tabular}

Berdasarkan hasil pengujian diperoleh nilai $\mathrm{t}$ hitung $<\mathrm{t}$ tabel atau sig $\rho$ value $<$ sig 0.05 berarti $0.796>0.05$. Dengan demikian Ho diterima dan $\mathrm{H} 1$ ditolak, hal ini menunjukkan tidak terdapat pengaruh yang signifikan secara parsial antara Kebutuhan (X1) terhadap Keputusan memilih (Y).

\section{F. Pengaruh Motivasi (X2) terhadap Keputusan memilih (Y) dengan Uji T}

Berdasarkan hasil pengujian diperoleh nilai $\mathrm{t}$ hitung $<\mathrm{t}$ tabel atau sig $\rho$ value $<$ sig 0.05 berarti $0.00<0.005$. Dengan demikian Ho ditolak dan $\mathrm{H} 2$ diterima, hal ini menunjukkan terdapat pengaruh yang signifikan secara parsial antara Motivasi (X2) terhadap Keputusan memilih (Y).

\section{G. Uji F}

Berikut ini disajikan data hasil Uji F, sebagai langkah terakhir untuk menentukan hasil akhir penelitian ini.
Tabel 7. Analisa Variansi

\begin{tabular}{|c|c|c|c|c|c|c|}
\hline \multicolumn{7}{|c|}{ ANOVAa $^{a}$} \\
\hline & Model & $\begin{array}{c}\text { Sum of } \\
\text { Squares }\end{array}$ & df & $\begin{array}{c}\text { Mean } \\
\text { Square }\end{array}$ & $\mathrm{F}$ & Sig. \\
\hline \multirow[t]{3}{*}{1} & Regression & 440.707 & 2 & 220.353 & 163.158 & $.000^{\mathrm{b}}$ \\
\hline & Residual & 97.240 & 72 & 1.351 & & \\
\hline & Total & 537.947 & 74 & & & \\
\hline \multicolumn{7}{|c|}{ a. Dependent Variable: Y } \\
\hline \multicolumn{7}{|c|}{ b. Predictors: (Constant), X2, X1 } \\
\hline
\end{tabular}

Berdasarkan hasil penelitian, menunjukkan bahwa kebutuhan (X1) dan Motivasi (X2) berpengaruh positif terhadap Keputusan memilih dengan diperoleh persamaan regresi $\mathrm{Y}=2,142+0.010 \mathrm{X} 1+0.942 \mathrm{X} 2$. Hasil analisis regresi ini menunjukkan koefisien dari masing-masing variabel bertanda positif, artinya semakin tinggi kebutuhan dan motivasi, maka akan semakin tinggi pula keputusan memilih.

Pengujian hipotesis diperoleh $F$ hitung > Ftabel atau $(163,158>2,740)$, hal tersebut juga diperkuat dengan probability significancy $0,000<0,05$. Dengan demikian H0 ditolak dan H3 diterima. Artinya terdapat pengaruh positif dan signifikan secara simultan antara kebutuhan dan motivasi terhadap keputusan memilih

\section{SIMPULAN DAN SARAN}

\section{A. SIMPULAN}

Berdasarkan uraian pada bab-bab sebelumnya, dan dari hasil analisis serta pembahasan mengenai pengaruh Kebutuhan (X1), Motivasi (X2) Walisantri terhadap keputusan memilih pondok pesantren modern Al Wafi Islamic Boarding School (Y) sebagai berikut :

1. Berdasarkan hasil pengujian diperoleh nilai t hitung $<\mathrm{t}$ tabel atau sig $\rho$ value $<\operatorname{sig}$ 0.05 berarti $0.796>0.005$. Dengan demikian Ho diterima dan H1 ditolak, hal ini menunjukkan tidak terdapat pengaruh yang signifikan secara parsial antara Kebutuhan (X1) terhadap Keputusan memilih (Y)

2. Berdasarkan hasil pengujian diperoleh nilai $\mathrm{t}$ hitung $<\mathrm{t}$ tabel atau sig $\rho$ value $<\operatorname{sig}$ 0.05 berarti $0.00<0.005$. Dengan demikian Ho ditolak dan $\mathrm{H} 2$ diterima, hal ini menunjukkan terdapat pengaruh yang signifikan secara parsial antara Motivasi (X2) terhadap Keputusan memilih (Y)

3. Berdasarkan hasil penelitian, menunjukkan bahwa kebutuhan (X1) dan Motivasi (X2) berpengaruh positif terhadap Keputusan memilih dengan diperoleh persamaan regresi $\mathrm{Y}=2,142+0.010 \mathrm{X} 1+0.942 \mathrm{X} 2$. Hasil analisis regresi ini menunjukkan 
koefisien dari masing-masing variabel bertanda positif, artinya semakin tinggi kebutuhan dan motivasi, maka akan semakin tinggi pula keputusan memilih.

Pengujian hipotesis diperoleh $\mathrm{F}$ hitung > Ftabel atau $(163,158>2,740)$, hal tersebut juga diperkuat dengan probability significancy $0,000<0,05$. Dengan demikian H0 ditolak dan H3 diterima. Artinya terdapat pengaruh positif dan signifikan secara simultan antara kebutuhan dan motivasi terhadap keputusan memilih

\section{B. SARAN}

Untuk memperbaiki kualitas penelitian ini, maka disampaikan beberapa saran yang dapat dijadikan acuan bagi peneliti berikutnya, antara lain:

1. Variabel kebutuhan (X1) pernyataan yang paling lemah adalah pernyataan Jika anak saya masuk pesantren moderen maka akan dapat memperbanyak teman dari berbagai daerah. Jadi Walisantri menitipkan dan bergabung ke Alwafi Boarding School bukan kebutuhan yang signifikan. Pondok Pesantren Alwafi dituntut kebutuhan yang bermanfaat buat santri dan harapan orang tua.

2. Variabel Motivasi (X2), pernyataan yang paling lemah adalah pernyataan banyaknya santri di Pesantren Moderen Al Wafi Islamic Boarding School (IBS) membuat saya mengambil keputusan untuk memasukkan anak saya ke Pesantren Moderen Al Wafi Islamic Boarding School (IBS). Untuk lebih baik lagi saran kami nantinya dengan semakin banyaknya santri yang bergabung ke Alwafi IBS diharapkan pengelola pesantren semakin meningkatkan mutu dan bekerjasama dengan institusi keagamaan baik dalam dan luar negeri.

3. Variabel Keputusan memilih (Y), adalah keputusan Walisantri untuk bergabung di pondok pesantren AlWafi Islamic Boarding School (IBS). Diharapkan dengan keputusan yang telah dipilih agar walisantri bekerjasama dan mendukung pengelola untuk memajukan dan mencerdaskan para santri.

\section{DAFTAR RUJUKAN}

Alma, Buchari. 2011. Manajemen Pemasaran dan Pemasaran Jasa. Bandung: Alfabeta.
Assauri, Sofjan. 2004. Manajemen Pemasaran. Jakarta: Rajawali Press.

Dede Andi, Muhamad Abid, Denok Sunarsi, \& Irfan Rizka Akbar. (2021). Implementasi Pendidikan Karakter Melalui Nilai-nilai Kearifan Lokal di Mts Darul Huda Kp. Cimuncang Kabupaten - Tasikmalaya. JIIP Jurnal Ilmiah Ilmu Pendidikan,4(3), 149153. Retrieved from http://jiip.stkipyapisdompu.ac.id/jiip/index .php/JIIP/article/view/227

Fajri, C. (2020). Pengaruh Kualitas Pelayanan Terhadap Tingkat Kepuasan Santriwati SMA AL Wafi Islamic Boarding School. INVEST: Jurnal Inovasi Bisnis dan Akuntansi, 1(2), 6367.

Ghozali, Imam. 2006. Aplikasi Analisis Multivariate dengan program SPSS. Semarang: Badan Penerbit Universitas Diponegoro.

Jamli, Edison dkk, (2005), Kewarganegaraan, Jakarta, Bumi Aksara. Kamus Besar Bahasa Indonesia, pusat bahasa (1991) Edisi 2, Jakarta, Balai Pustaka.

Kotler, Philip dan Armstrong, Garry. 2008. Prinsip-prinsip Pemasaran. Jakarta: Erlangga

Kotler, Philip. 2011. Manajemen Pemasaran di Indonesia: Analisis, Perencanaan, Implementasi dan Pengendalian. Jakarta: Salemba Empat.

Regita Puji Agustin, Adi Suparwo, Wulan Yuliyana, Denok Sunarsi, \& Nurjaya. (2021). Pengaruh Kualitas Pelayanan terhadap Kepuasan Pelanggan serta dampaknya pada Word of Mouth Jasa Pengurusan Nenkin di CV Speed Nenkin. JIIP - Jurnal Ilmiah Ilmu Pendidikan, 4(3), 186-190. Retrieved from http://jiip.stkipyapisdompu.ac.id/jiip/index .php/JIIP/article/view/249

Sugiyono, P. D. (2019). Metode Penelitian; Kualitatif, Kuantitatif dan Campuran. Bandung: Alfabeta.

Sutisna dan Sunyoto.Perilaku Konsumen \&Komunikasi Pemasaran. Bandung: Remaja Rosdakarya 